\title{
EFEKTIVITAS MODEL PEMBELAJARAN KNISLEY BERBASIS MASALAH TERHADAP KEMAMPUAN PEMECAHAN MASALAH MATEMATIS PADA POKOK BAHASAN PLDV
}

\author{
Muhammad Khoiril Akhyar ${ }^{1)}$, Muthi'ur Rokhmah ${ }^{2)}$ \\ 12)) Pendidikan Matematika Universitas Peradaban, Paguyangan, Brebes \\ odapiss2@gmai.com ${ }^{11}$, muthi.ind@gmail.com ${ }^{2)}$
}

\begin{abstract}
Abstrak
Penelitian ini bertujuan untuk mengetahui keefektifan model pembelajaran knisley berbasis masalah terhadap kemampuan pemecahan masalah matematis pada pokok bahasan PLDV. Pendekatan yang digunakan adalah pendekatan penelitian eksperimen dengan desain Posttest-Only Control Design. Analisis data yang digunakan diantaranya uji normalitas, uji homogenitas, uji kesamaan rata-rata, uji ketuntasan, uji banding dan uji regresi. Hasil dari penelitian ini diperoleh bahwa nilai rata-rata kemampuan pemecahan masalah matematis siswa melampaui 78 dengan proporsi siswa yang tuntas $88 \%$. Hasil tes kemampuan pemecahan masalah matematis siswa kelas eksperimen adalah 85 lebih baik dibanding rata-rata kemampuan pemecahan masalah matematis siswa kelas kontrol yaitu 75. Uji regresi sederhana menunjukan bahwa terdapat pengaruh positif aktivitas belajar siswa terhadap peningkatan kemampuan pemecahan masalah matematis siswa sebasar $70,2 \%$. Karena memenuhi ketiga kriteria keefektifan maka dapat disimpulkan bahwa model pembelajaran knisley berbasis masalah efektif terhadap kemampuan pemecahan masalah matematis siswa
\end{abstract}

Kata Kunci: Model Pembelajaran Knisley, Kemampuan Pemecahan Masalah Matematis

\begin{abstract}
This study aims to determine the effectiveness of the problem-based knisley learning model on mathematical problem solving abilities on the subject of PLDV. The approach used is an experimental research approach with the Posttest-Only Control Design design. Analysis of the data used include normality test, homogeneity test, average equality test, completeness test, comparative test and regression test. The results of this study found that the average value of students mathematical problem solving abilities exceeded 78 with the proportion of students who completed $88 \%$. The test results of students mathematical problem solving ability experimental class is 85 better than the average control class students mathematical problem solving ability of 75 . Simple regression test shows that there is a positive influence of student learning activities on improving students mathematical problem solving abilities as much as $70.2 \%$. Because it fulfills all three criteria of effectiveness, it can be concluded that the problem-based knisley learning model effective on students mathematical problem solving abilities..
\end{abstract}

Key Words : Model Knisley Learning, Problem solving Mathematcs Ability 


\section{PENDAHULUAN}

NCTM (2000: 29) menyatakan bahwa standar kemampuan matematis yang harus dimiliki oleh siswa adalah pemecahan masalah, penalaran dan bukti, komunikasi, koneksi, dan representasi. Menurut NCTM, pemecahan masalah merupakan bagian integral dalam pembelajaran matematika, sehingga hal tersebut tidak boleh dilepaskan dari pembelajaran matematika. Kemampuan pemecahan masalah harus dimiliki oleh semua individu. Bukan hanya bagi mereka yang akan mendalami matematika, melaikan juga bagi yang menerapkannya dalam bidang studi lain. Khususnya bagi peserta didik, karena peserta didik akan dihadapi dengan permasalahan yang tidak dapat diselesaikan secara langsung, baik masalah yang terdapat di dalam kelas maupun dalam kehidupan sehari-hari.

Berdasarkan laporan Badan Penelitian dan Pengembangan (2012: 46) bahwa hasil evaluasi TIMSS (Trends in Student Achievement in Mathematics and Science) tahun 2011 prestasi belajar matematika kelas VIII di Indonesia termasuk didalamnya kemampuan pemecahan masalah berada diposisi 5 besar dari bawah yaitu peringkat 41 dari 45 negara dengan perolehan nilai 386, di atas Arab, Maroko, Oman dan Ghana. Sehingga dapat disimpulan bahwa kemampuan pemecahan masalah matematika di Indonesia masih tergolong rendah.

Rendahnya kemampuan pemecahan masalah juga terjadi di kelas VIII SMP Negeri 1 Paguyangan. Hasil Ulangan Akhir Semester (UAS) gasal mata pelajaran matematika kelas VIII SMP Negeri 1 Paguyangan menunjukkan bahwa masih banyak siswa belum mampu mengerjakan soal-soal UAS matematika dengan baik. Hal ini ditunjukkan bahwa 90,8\% siswa belum mencapai kriteria ketuntasan minimal (KKM). Berdasarkan hasil analisis soal investigasi yang diberikan peneliti terkait kemapuan pemecaham masalah, 25 siswa dari 34 siswa kelas VIII I kemampuan pemecahan masalah matematisnya masih rendah. Mereka merasa kesulitan dalam memahami masalah berbentuk soal cerita dan menafsirkan ke dalam kalimat matematika.

Materi persamaan linier dua variabel (PLDV) merupakan salah satu materi yang sanat memerlukan kemampuan pemecahan masalah matematis. Siswa dituntut untuk bisa menentukan unsur-unsur yang diketahui, ditanyakan, dan unsur-unsur lainnya serta mampu menentukan dan menerapkan strategi untuk menyelesaikan sebuah permasalahan. Oleh karena itu, siswa harus dilatih kemampuan pemecahan masalah matematisnya, agar dapat menyelesaikan persoalan dalam materi PLDV.

Model pembelajaran knisley berbasis masalah merupakan salah satu model pembelajaran yang dibangun oleh masalah. Masalah yang digunakan adalah masalah yang relevan dengan tujuan pembelajaran, mutakhir dan menarik. Penelitian 
Romadhoni (2016), mengenai Implementasi Model Pembelajaran Matematika Knisley (MPMK) dalam Meningkatkan Kemampuan Komunikasi Matematis Siswa dan Respon Siswa dalam Pembelajaran menunjukkan bahwa rerata skor nilai siswa mengalami peningkatan disetiap pertemuan, serta dari hasil angket respon diketahui rerata skor siswa memberi respon yang positif terhadap pembelajaran.

Berdasarkan latarbelakang tersebut peneliti tertarik untuk mengetahui keefektifan model pembelajaran knisley berbasis masalah terhadap kemampuan pemecahan masalah matematis pada pokok bahasan PLDV. Keefektifan dilihat dari tingkat ketuntasan kemampuan pemecahan masalah matematis siswa, perbandingan

kemampauan pemecahan masalah matematis siswa kelas eksperimen dengan kelas kontrol dan pengaruh aktivitas belajar siswa terhadap kemampuan pemecahan masalah matematis siswa.

\section{LANDASAN TEORI}

\section{Model Pembelajaran Knisley}

Kolb dikenal dengan model pembelajaran experiental laerning yaitu sebuah cara yang terjadi tibatiba, dengan menggunakan praktik pelatihan dan pengajaran yang tersituasikan dan mendorong perkembangan seseorang (Indriana, 2011: 89). Teori ini mendefinisikan belajar sebagai proses dimana pengetahuan diciptakan melalui transformasi pengalaman (experience).
Pengetahuan merupakan hasil perpaduan antara memahami dan mentransformasi pengalaman (Baharuddin \& Wahyuni, 2010: 165). Kolb (Budiningsih, 2005: 70-71) membagi tahap-tahap belajar menjadi empat, yaitu:

1. Tahap Pengalaman Konkret

2. Tahap Pengamatan Aktif dan Reflektif

3. Tahap Konseptualisasi

4. Tahap Eksperimen Aktif

Secara teoritis tahap-tahap belajar tersebut memang dapat dipisahkan, namun dalam kenyataannya proses peralihan dari satu tahap ke tahap belajar diatas sering kali terjadi begitu saja sulit untuk ditentukan kapan terjadinya.

Jeff Knisley adalah seorang asisten profesor matematika di East Tennessee State University (Knisley, 2002: 11). Knisley mengembangkan model pembelajaran yang diadopsinya dari model pembelajaran David Kolb (Knisley, 2002: 11) yang berpendapat bahwa, gaya belajar ditentukan oleh dua faktor, yang pertama apakah siswa lebih suka konkret daripada abstrak. Kedua, apakah siswa lebih suka eksperimentasi aktif daripada observasi reflektif. Adapun langkahlangkah pembelajaran model knisley (Knisley, 2002: 12-13):

\section{Allegori zation}

Siswa mempelajari konsep baru berdasarkan konsep yang dimilikinya dari pengalaman belajar sebelumnya. Pada tahap ini, peserta didik belum mampu membedakan konsep baru dengan konsep yang telah diketahui. 
Guru bertindak sebagai storyteller atau pencerita, yaitu guru menjelaskan konsep secara figuratif dalam konteks yang familiar berdasarkan istilahistilah yang terkait dengan konsep yang telah diketahui peserta didik.

\section{Integration}

Peserta didik melakukan eksplorasi, percobaan, mengukur, atau membandingkan konsep baru dengan konsep-konsep yang telah diketahuinya. Pada tahap ini, peserta didik menyadari konsep baru, tetapi tidak tahu bagaimana kaitannya dengan konsep yang sudah diketahui. Guru bertindak sebagai pembimbing dan pemberi motivasi.

\section{Analysis}

Peserta didik menganalisis, membuat atau memilih pernyataan yang terkait dengan konsep baru, memberi contoh kontra untuk menyangkal pernyataan yang salah, dan membuktikan pernyataan yang benar bersama-sama dengan guru. Pada tahap ini guru bertindak sebagai sumber informasi.

\section{Synthesis}

Peserta didik menggunakan konsep baru untuk memecahkan masalah. Pada tahap ini guru bertindak sebagai coach atau pelatih.

\section{Pembelajaran Berbasis Masalah}

Menurut Trianto (2015: 63) pembelajaran berbasis masalah yaitu suatu model pembelajaran yang didasarkan pada prinsip menggunakan masalah sebagai titik awal akuisisi dan integrasi pengetahuan baru. Pembelajaran berbasis masalah merupakan rangkaian aktivitas pembelajaran yang menekankan pada proses penyelesaian masalah yang dihadapi secara ilmiah (Sanjaya, 2009: 214). Jadi pembelajaran berbasis masalah merupakan pembelajaran yang diawali dengan pemberian masalah kepada siswa sebagai rangkaian aktivitas pembelajaran yang menekankan pada proses penyelesaian masalah yang dihadapi secara ilmiah.

\section{Kemampuan Pemecahan Masalah Matematis}

NCTM

(2000:

mengemukakan bahwa pemecahan masalah merupakan proses menerapkan pengetahuan yang telah diperoleh sebelumnya pada situasi baru dan berbeda. Menurut para ahli (Shadiq, 2004: 10) pemecahan masalah merupakan pertanyaan yang harus dijawab atau direspon. Namun mereka menyatakan juga bahwa tidak semua pertanyaan otomatis akan menjadi masalah. Suatu pertanyaan akan menjadi masalah hanya jika pertanyaan itu menunjukkan adanya suatu tantangan yang tidak dapat dipecahkan oleh suatu prosedur rutin. Jadi pemecahan masalah adalah proses menggunakan langkah-langkah tertentu untuk menemukan solusi suatu masalah. Adapun indikator pemecahan masalah menurut Polya (1973) adalah sebagai berikut:

1. Memahami masalah artinya siswa menuliskan apa yang diketahui dan ditanyakan dalam bentuk kalimat 
matematika yang bersesuaian.

Sebagai contoh, siswa mengilustrasikan soal dalam bentuk gambar lalu diberi keterangan yang diketahui dan ditanyakan.

2. Menyusun rencana artinya siswa menghubungkan pengetahuan yang dimiliki sebelumnya atau masalah serupa yang pernah diselesaikan, dengan yang diketahui dan ditanyakan dalam soal sehingga dapat membuat rencana penyelesaian.

3. Melaksanakan rencana artinya siswa melakukan perhitungan sesuai rencana yang telah disusun.

4. Memeriksa kembali, siswa melakukan koreksi ulang tentang penyelesaian masalah yang dibuat.

\section{METODE PENELITIAN}

\section{Jenis Penelitian}

Jenis penelitian ini adalah penelitian eksperimen, dalam penelitian eksperimen terdapat pemberian treatment atau perlakuan. Pemberian treatment tersebut bertujuan untuk mengetahui pengaruh dari treatment yang diberikan. Penelitian eksperimen ini pemberian treatmentnya adalah penerapan model pembelajaran knisley berbasis masalah terhadap kemampuan pemecahan masalah matematis siswa. Design eksperimen yang digunakan pada penelitian ini adalah "Posttest-Only Control Design". Dalam desain ini terdapat dua kelas yang masingmasing dipilih secara random.

\section{Waktu dan Tempat Penelitian}

Penelitian ini dilaksanakan di salah satu SMP Negeri 1 Paguyangan. Waktu yang digunakan peneliti untuk mengadakan penelitian yaitu pada semester genap tahun pelajaran 2016/2017.

\section{Subjek Penelitian}

Populasi yang digunakan adalah siswa kelas VIII pada salah satu SMP Negeri 1 Paguyangan yang terdiri dari sembilan kelas tahun pelajaran 2016/2017. Sampel dalam penelitian ini kelas adalah VIII I sebagai kelas eksperimen dan kelas VIII F sebagai kelas kontrol.. Teknik pengambilan sampel dalam penelitian ini menggunakan Simple Random Sampling.

Data, Intrumen, dan Teknik Pengumpulan Data

Intrumen pada penelitian ini ialah wawancara, observasi, dokumentasi, dan Tes.

\section{Teknik Analisis Data}

Teknik analisis data yang digunakan adalah uji ketuntasan, uji banding dan diakhiri dengan analisis regresi sederhana. Analisis data tersebut menggunakan aplikasi statistik SPSS 23.

\section{HASIL PENELITIAN}

1. Pengaruh Aktivitas Siswa pada Model Pembelajaran

CooperativeScript terhadap

Kemampuan Komunikasi

Matematis Siswa

Hasil dari posttest yang dilakukan pada kelas yang 
menggunakan model pembelajaran knisley berbasis masalah telah tuntas KKM. Dari jumlah siswa 34 anak, diketahui bahwa 30 anak telahtuntas KKM, yaitu sebesar $88 \%$ siswa telah tuntas dengan nilai rata-rata kemampuan pemecahan masalah matematis siswa menggunakan model pembelajaran knisley berbasis masalah pada materi PLDV sebesar 85. Standar nilai KKM mata pelajaran matematika yang ditentukan oleh sekolah yang diteliti adalah 78. Hasil uji ketuntasan rata-rata dapat dilihat pada Tabel. 1 . Pada tabeldiperoleh nilai thitung = 6,872 dengan $\alpha=5 \%$ dan $\mathrm{dk}=34-1$ $=33$ diperoleh nilai $\mathrm{t}_{\text {tabel }}=1,69236$. Karena $t_{\text {hitung }} \geq t_{\text {tabel }}=6,872 \geq 1,69236$, maka $\mathrm{H}_{0}$ ditolak. Uji proporsi yang menunjukan bahwa $z_{\text {hitung }} \geq z_{-}$(0,5- $\left.\alpha\right)$ $=1,797 \geq 1,64$ maka $\mathrm{H}_{0}$ ditolak, sehingga kemampuan pemecahan masalah matematis siswa yang menggunakan model pembelajaran knisley berbasis masalah telah mencapai ketuntasan.

Tabel 1. Hasil Uji Ketuntasan Rata-rata

\begin{tabular}{cccc}
\hline & \multicolumn{3}{c}{ Test value $=\mathbf{7 7 . 9}$} \\
\hline & $\mathbf{T}$ & df & Sig.(2-tailed) \\
\hline Kelas Eksperimen & 6,872 & 33 &, 000 \\
\hline
\end{tabular}

Proses pembelajaran dengan model knisley berbasis masalah pada kelas eksperimen dilakukan sebanyak tiga kali pertemuan. Penerapan model knisley berbasis masalah dalam pembelajaran matematika mampu merangsang siswa untuk belajar menyelesaikan masalah. Pembelajaran pada pertemuan pertama, siswa mengalami kesulitan beradaptasi ketika melakukan tahap integration karena siswa tidak terbiasa dengan hal tersebut. Ketika guru memberikan masalah yang harus dipecahkan secara berkelompok, siswa masih kurang tepat dalam menuliskan strategi pemecahan masalah, melakukan perhitungan dan memeriksa kembali ketepatan jawaban. Sehingga indikator kemampuan pemecahan masalah matematis yang dapat dicapai siswa hanya memahami masalah yaitu menuliskan yang diketahui dan ditanyakan saja.

Pembelajaran pada pertemuan kedua, siswa dapat menemukan dan menggunakan konsep baru, karena peserta didik yang belajar menyelesaikan suatu masalah akan menerapkan pengetahuan yang dimilikinya dan mengaplikasikannya dalam konteks yang relevan. Hal tersebut dapat mempermudah siswa dalam menyelesaikan masalah yang sedang dihadapi.Pertemuan ketiga, siswa sudah bisa mengikuti setiap langkah pembelajaran dengan baik.Hal tersebut sejalan dengan penelitian Anggreavi (2016) yang menyimpulkan bahwa pembelajaran matematika melalui model pembelajaran knisley dapat meningkatkan hasilbelajarmatematika siswa. Dimana kemampuan pemecahan masalah juga 
merupakan hasil belajar matematika.

Sehingga kemampuan pemecahan masalah matematis siswa akan meningkat dengan model pembelajaran knisley berbasis masalah dandapat mencapai ketuntasan minimum.

Hasil perbandingan dari rata-rata kemampuan pemecahan masalah matematis siswa kelas eksperimen yang menggunakan model pembelajaran knisley berbasis masalah lebih baik dari rata-rata kemampuan pemecahan masalah matematis siswa kelas kontrol yang menggunakan pembelajaran dengan modelkonvensional. Nilai rata-rata kemampuan pemecahan masalah matematis siswa yang menggunakan model pembelajaran knisley berbasis masalah adalah 85 dengan jumlah siswa yang tuntas sebanyak 30 anak dari 34 anak, sedangkan nilai rata-rata kemampuan pemecahan masalah matematis siswa yang menggunakan pembelajaran dengan model konvensional adalah 75 dengan jumlah siswa yang tuntas sebanyak 14 anak dari 38 anak. Hasil uji banding dengan menggunakan SPSS 23 dapat dilihat pada Tabel. 2. Hasil uji banding menunjukkan bahwa baris Equal variances assumed diperoleh nilai $\mathrm{t}=$ 6,136 , dengan $\mathrm{dk}=(34+38-2)=70$ dan $\alpha=0,05$ diperoleh $\mathrm{t}_{\text {tabel }}=1,66691$, maka $t_{\text {hitung }}>\mathrm{t}_{\text {tabel }}=6,136>1,66691$ sehingga $\quad \mathrm{H}_{0} \quad$ ditolak.

Tabel. 2. Hasil Uji Beda Rata-rata

\begin{tabular}{|c|c|c|c|c|c|c|}
\hline & & \multicolumn{2}{|c|}{$\begin{array}{c}\text { Levene's Test for } \\
\text { Equality of } \\
\text { Variances }\end{array}$} & \multicolumn{3}{|c|}{ t-test for Equality of Means } \\
\hline & & $\mathrm{F}$ & Sig. & $\mathrm{t}$ & df & Sig. (2-tailed) \\
\hline \multirow[t]{2}{*}{$\begin{array}{l}\text { Nilai } \\
\text { Posttest }\end{array}$} & $\begin{array}{l}\text { Equal } \\
\text { variances } \\
\text { assumed }\end{array}$ & 1,558 &, 216 & 6,136 & 70 &, 000 \\
\hline & $\begin{array}{l}\text { Equal } \\
\text { variances not } \\
\text { assumed }\end{array}$ & & & 6,214 & 69,118 & 000 \\
\hline
\end{tabular}

Kelas kontrol guru menggunakan pembelajaran dengan model konvensional. Hasil pengamatan, terlihat guru selalu menerangkan, baik dalam menyampaikan materi maupun pembahasan soal-soal yang diberikan sebagai latihan. Siswa hanya melihat dan mendengarkan, dalam kegiatan pembahasan soal latihan yang diberikan, siswa tidak pernah terlibat dalam penyelesaiannya, guru selalu menjadi pusat dalam pembelajaran. Hal tersebut mengakibatkan siswa merasa jenuh dan bosan dengan kegiatan pembelajaraan yang monoton dan tidak adanya keterlibatan siswa di dalamnya. Sehingga materi yang disampaikan maupun penjelasan 
contoh soal yang diberikan tidak tertangkap oleh siswa. Dampaknya hasil belajar termasuk kemampuan pemecahan masalah matematis siswa menjadi rendah.

Kelas eksperimen diberikan treatment dengan menggunakan model pembelajaran knisley berbasis masalah. Dalam kegiatan pembelajaran, guru menceritakan suatu masalah dengan tujuan terbentuknya konsep baru, yang nantinya siswa dapat menyelesaikan persoalan secara individu. Pada tahap awal pembentukan konsep baru, masalah tersebut diselesaikan oleh siswa secara berkelompok. Guru hanya sebagai pembimbing dan motivator.Pada awalnya siswa memang kesulitan untuk beradaptasi ketika melakukan tahapan-tahapan yang ada pada pembelajaran model knisley berbasis masalah. Masih kesulitan juga ketika menyusun strategi penyelesaian masalah, melakukan perhitungan dan memeriksa kembali ketepatan jawaban, akan tetapi pada pertemuan kedua dan ketiga siswa dapat melakukannya dengan baik selama kegiatan belajar mengajar berlangsung. Pada pertemuan kedua dan ketiga secara tidak langsung siswa dapat mengerjakan soal secara individu atau tanpa bantuan guru. Pembelajaran yang demikian akan membentuk dan meningkatkan kemampuan pemecahan masalah matematis siswa.

Hal tersebut diperkuat dengan pernyataan Romadhoni (2016) dalam penelitiannya yang menyatakan bahwa model pembelajaran matematika knisley dapat meningkatkan prestasi belajar dari satu siklus ke siklus berikutnya serta siswa memberi respon yang positif terhadap pembelajaran. Dimana kemampuan pemecahan masalah matematis siswa juga termasuk dalam prestasi belajar matematika. Penggunaan pembelajaran model knisley berbasis masalah semakin membentuk siswa untuk bisa menyelesaikan sebuah permasalahan secara individu.

Tabel. 3. Hasil Uji Persamaan Linier

\begin{tabular}{llrrrrr}
\hline \multirow{2}{*}{ Model } & & Sum of & \multicolumn{2}{c}{ Mean } & & \\
\hline 1 & Regression & Squares & Df & Square & F & Sig. \\
& Residual & 798,996 & 1 & 798,996 & 75,212 &, $000^{6}$ \\
& Total & 339,945 & 32 & 10,623 & & \\
& 1138,941 & 33 & & & \\
\hline
\end{tabular}

a. Dependent Variable: Kemampuan Pemecahan Masalah Matematis

b. Predictors: (Constant), Aktivitas Belajar Siswa

Tabel. 3.menunjukkan nilai sig $=0,000<0,05$ maka $\mathrm{H} 0$ ditolak. Artinya persamaan adalah linier atau ada pengaruh antara aktivitas belajar siswa dengan kemampuan pemecahan masalah matematis siswa. 
Tabel. 4. Hasil Koefisien Determinasi

\begin{tabular}{|c|c|c|c|c|c|c|}
\hline \multirow[b]{2}{*}{ Model } & & \multicolumn{2}{|c|}{$\begin{array}{c}\text { Unstandardized } \\
\text { Coefficients }\end{array}$} & $\begin{array}{l}\text { Standardized } \\
\text { Coefficients }\end{array}$ & \multirow[b]{2}{*}{$\mathrm{t}$} & \multirow[b]{2}{*}{ Sig. } \\
\hline & & B & $\begin{array}{l}\text { Std. } \\
\text { Error }\end{array}$ & Beta & & \\
\hline \multirow[t]{2}{*}{1} & (Constant) & 28,402 & 6,530 & & 4,350 &, 000 \\
\hline & $\begin{array}{l}\text { Aktivitas } \\
\text { Belajar Siswa }\end{array}$ & ,881 & , 102 & ,838 & 8,672 &, 000 \\
\hline
\end{tabular}

a. Dependent Variable: Kemampuan Pemecahan Masalah Matematis

Berdasarkan Tabel. 4.diperoleh bahwa pada output coefficients nilai a $=28,402$ dan $\mathrm{b}=0,881$ (dapat dilihat pada kolom yang dilingkari). Jadi persamaan regresi $\mathrm{Y}^{\wedge}=\mathrm{a}+\mathrm{bX}=28,402+$ $0,881 \mathrm{X}$,artinya jika nilai $\mathrm{x}$ naik sebesar satu satuan maka nilai y akan naik sebesar 0,881 satuan. Sehingga aktivitas belajar siswa menggunkan model knisley berbasis masalah berpengaruh positif terhadap kemampuan pemecahan masalah matematis siswa.

Tabel. 5. Besar Pengaruh Aktivitas Belajar Siswa

\begin{tabular}{lrrrr}
\hline Model & $\mathrm{R}$ & R Square & $\begin{array}{c}\text { Adjusted R } \\
\text { Square }\end{array}$ & \multicolumn{2}{c}{$\begin{array}{c}\text { Std. Error of the } \\
\text { Estimate }\end{array}$} \\
\hline 1 &, $838^{\mathrm{a}}$ &, 702 &, 692 & 3,259 \\
\hline
\end{tabular}

a. Predictors: (Constant), Aktivitas Belajar Siswa

Pengaruh dari aktivitas belajar siswa tehadap kemampuan pemecahan masalah matematis siswa adalah $70,2 \%$ sedangkan $29,8 \%$ dipengaruhi oleh faktor lain. Besar pengaruh dapat dilihat pada Tabel. 5. Hasil posttest dan hasil pengamatan aktivitas belajar siswa menunjukkan bahwa hasil pengamatan aktivitas belajar siswa mempengaruhi hasil posttest kemampuan pemecahan masalah matematis siswa pada pokok bahasan PLDV yang menggunakan model pembelajaran knisley berbasis masalah. Proses pembelajaran dalam penelitian ini dilakukan selama tiga kali pertemuan dengan menggunakan model pembelajaran knisley berbasis masalah. Selama tiga kali pertemuan tersebut, dari lembar aktivitas belajar siswa yang dinilai oleh observer, hasilnya terdapat peningkatan aktivitas belajar siswa yang diringi pula dengan peningkatan kemampuan pemecahan masalah matematis siswa dalam menyelesaian sebuah permasalahan.Hal ini diperkuat oleh Sam \& Qohar (2015) dalam penelitiannya yang menyimpulkan bahwa pembelajaran berbasis masalah berdasarkan langkah-langkah polya dapat meningkatkan kemampuan penyelesaian soal cerita matematika siswa kelas VIII. 


\section{SIMPULAN DAN SARAN}

\section{Simpulan}

Berdasarkan analisis data dan pembahasan, maka dapat disimpulkan bahwa:

(1) Siswa yang pembelajarannya menggunakan model pembelajaran knisley berbasis masalah memiliki kemampuan pemecahan masalah matematis yang baik, siswa mampu memecahkan masalah atau persoalan secara sistematis.

(2) Siswa yang pembelajarannya menggunakan model pembelajaran knisley berbasis masalah memiliki rata-rata kemampuan pemecahan masalah matematis lebih tinggi daripada nilai rata-rata siswa yang pembelajarannya menggunakan metode konvensional.

(3) Aktivitas belajar siswa pada pembelajaran model knisley berbasis masalah memiliki hubungan fungsional linier dan signifikan terhadap kemampuan pemecahan masalah matematis siswa. Besarnya pengaruh aktivitas belajar siswa terhadap kemampuan pemecahan matematis siswa yaitu 70,2\%. Jadi dapat disimpulkan bahwa aktivitas belajar siswa berpengaruh positif terhadap kemampuan pemecahan masalah matematis siswa.

\section{Saran}

Berdasarkan hasil yang sudah didapat selama melakukan penelitian, maka peneliti memberikan saran-saran sebagai berikut:

1. Sebelum pelaksanaan pembelajaran dengan model Knisley hendaknya sudah mempersiapkan dengan baik langkah-langkah dari model knisley berbasis masalah agar siswa tidak kebingungan pada saat pembelajaran.

2. M model knisley berbasis masalah dapat dijadikan sebagai salah satu alternatif model pembelajaran yang dapat digunakan dalam pembelajaran matematika untuk meningkatkan kemampuan pemecahan masalah matematis

3. Hasil penelitian ini dapat dijadikan sebagai referensi dalam penelitian yang sejenis dengan variabel-variabel yang berbeda. Selain itu, penelitian ini menerapkan model knisley berbasis masalah yang tidak hanya diterapkan pada materi SPLDV, tetapi juga diterapkan pada materi lain.

\section{DAFTAR PUSTAKA}

Anggreavi, S. S. (2016). "Efektivitas Model Pembelajaran Knisley Terhadap Kemampuan Pemahaman Matematis Peserta Didik Kelas X SMA Materi Pokok Trigonometri Di SMA N 8 Semarang Tahun Pelajaran 2015/2016". Skripsi UIN Walisongo, Semarang, 2016.

Badan Penelitian dan Pengembangan. (2012).Kemampuan Matematika 
Siswa SMP Indonesia Menurut Benchmark Internasional TIMSS 2011. Kementrian Pendidikan dan Kebudayaan.

- Baharuddin dan Wahyuni, E., N. (2010). Teori Belajar dan Pembelajaran. Yogyakarta: ArRuzz Media.

Budiningsih, C. A. (2005). Belajar dan Pembelajaran. Jakarta: Rineka Cipta.

Indriana, D. (2011). Mengenal Ragam Gaya Pembelajaran Efektif. Yogyakarta: Diva Press.

Knisley, J. (2002). “A Four-Stage

Model of Mathematical Learning", The Mathematics Educator. Vol. 12. 11-16.

NCTM. (2000). Principles and Standards for School

Mathematics. Reston, VA: NCTM.

Polya, G. (1973). How To Solve It:

Second Edition. United States of

America: Princeton University Press.

Romadhoni, Erlina, M., C. (2016). "Implementasi Model

Pembelajaran Matematika Knisley (MPMK) dalam Upaya Meningkatkan Kemampuan Komunikasi Matematis Siswa dan Respon Siswa dalam Pembelajaran". Prosiding Konferensi Nasional Penelitian Matematika dan Pembelajarannya. Surakarta.

Sam, H., N. \& Qohar, A. (2015). "Pembelajaran Berbasis Masalah Berdasarkan Langkah-Langkah Polya untuk Meningkatkan Kemampuan Menyelasaikan Soal Cerita Matematika". Kreano Journal UNNES. Vol. 6 (2). 156-163.

Sanjaya, W. (2009). Strategi Pembelajaran Berorientasi Standar Proses Pendidikan. Jakarta: Kencana Prenada Media Group.

Shadiq, F. (2004). Pemecahan Masalah, Penalaran dan Komunikasi dalam Pembelajaran Matematika. Yogyakarta: depdiknas dirjen dikdasmen PPPG matematika.

Trianto. (2015). Mendesain Model Pembelajaran Inovatif, Progresif dan Kontekstual: Konsep, Landasan dan Implementasinya pada Kurikulum 2013 (Kurikulum Tematik Integratif/ TKI). Jakarta: Prenadamedia Group. 
